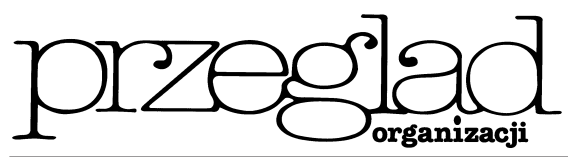

\title{
Co pobudza przedsiębiorstwa do wdrażania innowacji?
}

https://doi.org/10.33141/po.2005.78.05

Jerzy Baruk
Przegląd Organizacji, Nr 7/8 (786/787), 2005, ss. 21-25

www.przegladorganizacji.pl Towarzystwo Naukowe Organizacji i Kierownictwa (TNOiK)

\section{Wstęp \\ W} spółczesne przedsiębiorstwo powinno zmieniać swoją mentalność i ograniczać wszelkie bariery ${ }^{1}$ pojawiające się na drodze do systematycznej innowacji, która najczęściej jest rezultatem umiejętnego patrzenia na codzienną rzeczywistość z innej perspektywy niż czyni to większość. Zasadne jest więc, aby każdy kierownik ${ }^{2}$ :

- traktował swoją organizację jak zbiór zasobów (własnych i zewnętrznych) i umiejętności, które trzeba wykorzystać na rzecz zaspokojenia potrzeb klientów;

- kształtował w sobie i w swoich podwładnych umiejętność myślenia kategoriami klientów, proponowania nowości kierując się intuicją, a nie tylko wynikami analiz;

- dostrzegał pojawiające się tendencje ( $\mathrm{w}$ modzie, technice, polityce, rozrywce itp.), które nie zostały jeszcze zauważone przez innych, a które mogą stać się inspiracją do innowacji;

- nie ulegał dogmatom i ortodoksjom;

- posiadał umiejętność kwestionowania obowiązujących poglądów na temat swojej branży i poszukiwania możliwości radykalnych przełomów;

- posiadał zdolność myślenia nie tylko w kategoriach wyłącznie konkurencji i konfliktu, ale głównie w kategoriach zależności i współpracy;

- akceptował zarządzanie interaktywne, partnerskie.

W obecnej dobie kierownicy przedsiębiorstw muszą zrozumieć, że nie funkcjonują już w epoce postępu, lecz w erze rewolucji, w której miejsce liniowych zmian zajmują przełomy i skoki rozwojowe ${ }^{3)}$. Konieczne są więc innowacje w koncepcjach biznesu; niezbędne staje się opanowanie sztuki przewidywania przyszłych życzeń klientów i przekształcanie ich na innowacje ${ }^{4)}$. Przy entuzjastycznym nastawieniu członków zarzadu nawet ospałe przedsiębiorstwo może stać się "gwiazdą" biznesu, jeżeli nabędzie zdolności do trafnego wypatrywania rewolucyjnych możliwości, tak jak czynił to Enron, owego czasu uchodzacy za najbardziej innowacyjne przedsiębiorstwo USA ${ }^{5}$.

Na początku XXI wieku obserwuje się wyraźny wzrost zainteresowania uczestników rynku wzajemnymi stosunkami i sposobem ich nawiązywania ${ }^{6}$. Coraz ważniejsze stają się interakcyjne relacje między organizacją i innymi podmiotami gry rynkowej. Następuje przesunięcie punktu ciężkości w funkcjonowaniu i rozwoju organizacji z jednostkowych transakcji w kierunku budowy długookresowych i trwałych relacji z wybranymi partnerami ${ }^{7}$. Partnerskie relacje, zwłaszcza w kontekście budowania i wykorzysta- nia kluczowych kompetencji, odgrywają ważną rolę w działalności innowacyjnej pod warunkiem odpowiedniego nastawienia do partnerstwa kadry kierowniczej. Podstawowe znaczenie dla takiego procesu posiada uczenie się poprzez dobrze zarządzaną działalność innowacyjną, prowadzoną we własnym zakresie lub we współpracy z organizacjami zewnętrznymi ${ }^{8)}$.

Dlatego badanie postaw kadry kierowniczej wobec innowacji staje się coraz ważniejsze ze względu na wyjaśnienie paradygmatu zarządzania. Niestety, takie badania nie sa powszechnym zjawiskiem. $\mathrm{Z}$ zadowoleniem należy więc przyjąć każdą nowość w tym zakresie. Jedna z nich to badania podjęte w Unii Europejskiej na użytek Komisji Europejskiej. Ostatnie badania na temat „Innowacje w 2003: doświadczenia i priorytety europejskich kierowników" przeprowadzono we wrześniu 2003 roku $^{9}$. Badaniu kwestionariuszowemu poddano 3010 kierowników (przedstawicieli zarząáó) przedsiębiorstw zatrudniających przynajmniej 20 pracowników w 15 państwach członkowskich Unii Europejskiej. Celem tych badań było poznanie opinii tzw. top managers na temat ${ }^{10}$ :

- potrzeb przedsiębiorstw w zakresie innowacji,

- inwestycji przeznaczanych przez przedsiębiorstwa na działalność innowacyjną,

- sił napędzających działalność innowacyjną,

- wpływu rynku na aktywność innowacyjną,

- nowych podejść do zarządzania innowacjami,

- korzyści dla przedsiębiorstw wynikających ze wspólnego rynku.

\section{Czynniki motywujące przedsiębiorstwa Unii Europejskiej do wprowadzania innowacji}

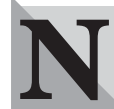

iewątpliwie ciągle aktualne jest pytanie: co sprawia, że przedsiębiorstwa decydują się na wdrażanie innowacji, czy zainteresowanie kierowników tą problematyką wywołują czynniki zewnętrzne, wewnętrzne, a może jedne i drugie? Próbę odpowiedzi na te pytania podjęto na podstawie wspomnianych we wstępie badań empirycznych. Jedno z pytań zadanych kierownikom wymagało wskazania czynników dostarczających najsilniejszych bodźców do wprowadzania innowacji w przedsiębiorstwie w ciagu ostatnich dwóch lat. Odpowiedzi odnoszące się do Unii Europejskiej (UE) jako całości oraz do poszczególnych państw członkowskich przedstawiono w tabeli 1 . Wynika z niej, że „odpowiedź na potrzeby konsumentów” stanowiła najsilniejszy bodziec do wprowadzania innowacji dla 35\% kierowników w UE. Wymowa tego wskaźnika posiada znacznie szersze konsekwencje dla procesów decyzyjnych, warunkiem kreatywnego re- 
Tab. 1. Czynniki dostarczające najsilniejszych bodźców do wprowadzania innowacji w przedsiębiorstwie w ciągu ostatnich dwóch lat

\begin{tabular}{|c|c|c|c|c|c|c|c|}
\hline \multirow{3}{*}{ Wyszczególnienie } & \multicolumn{7}{|c|}{ Rodzaje czynników } \\
\hline & $\begin{array}{l}\text { Odpowiedź } \\
\text { na potrze- } \\
\text { by konsu- } \\
\text { mentów }\end{array}$ & $\begin{array}{l}\text { Wzrastają- } \\
\text { ca konku- } \\
\text { rencja } \\
\text { cenowa }\end{array}$ & $\begin{array}{l}\text { Wzrastaja- } \\
\text { ca konku- } \\
\text { rencja } \\
\text { produk- } \\
\text { towa }\end{array}$ & $\begin{array}{c}\text { Potrzeba } \\
\text { poprawy } \\
\text { poziomu } \\
\text { wydajności } \\
\text { pracowni- } \\
\text { ków }\end{array}$ & $\begin{array}{c}\text { Potrzeba } \\
\text { poprawy } \\
\text { poziomu } \\
\text { wydajności } \\
\text { maszyn } \\
\text { i urządzeń }\end{array}$ & \begin{tabular}{|c|} 
Dostoso- \\
wanie sie \\
do nowych \\
regulacji \\
lub zobo- \\
wiązań \\
prawnych
\end{tabular} & $\begin{array}{c}\text { Brak } \\
\text { odpo- } \\
\text { wiedzi }\end{array}$ \\
\hline & \multicolumn{7}{|c|}{ Procent odpowiedzi (przedsiębiorstw) } \\
\hline $\begin{array}{l}\text { Unia Europejska } \\
\text { (15 UE) } \\
\text { - Niemcy } \\
\text { - Dania } \\
\text { - Austria } \\
\text { - Wielka Brytania } \\
\text { - Hiszpania } \\
\text { - Irlandia } \\
\text { - Holandia } \\
\text { - Szwecja } \\
\text { - Finlandia } \\
\text { - Portugalia } \\
\text { - Francja } \\
\text { - Luksemburg } \\
\text { - Belgia } \\
\text { - Grecja } \\
\text { - Włochy }\end{array}$ & $\begin{array}{l}35 \\
47 \\
46 \\
41 \\
36 \\
35 \\
35 \\
34 \\
34 \\
30 \\
29 \\
28 \\
27 \\
22 \\
21 \\
16\end{array}$ & $\begin{array}{r}14 \\
15 \\
17 \\
12 \\
12 \\
9 \\
19 \\
14 \\
14 \\
17 \\
15 \\
14 \\
12 \\
9 \\
14 \\
15\end{array}$ & $\begin{array}{r}11 \\
9 \\
9 \\
8 \\
14 \\
11 \\
9 \\
8 \\
10 \\
13 \\
10 \\
11 \\
10 \\
13 \\
20 \\
12\end{array}$ & $\begin{array}{r}13 \\
14 \\
14 \\
5 \\
11 \\
14 \\
11 \\
9 \\
15 \\
10 \\
12 \\
16 \\
26 \\
21 \\
19 \\
11\end{array}$ & $\begin{array}{r}13 \\
7 \\
7 \\
9 \\
9 \\
19 \\
10 \\
14 \\
17 \\
9 \\
24 \\
8 \\
14 \\
17 \\
14 \\
33\end{array}$ & $\begin{array}{r}10 \\
6 \\
5 \\
13 \\
13 \\
7 \\
12 \\
13 \\
3 \\
6 \\
6 \\
19 \\
6 \\
13 \\
10 \\
12\end{array}$ & $\begin{array}{r}4 \\
3 \\
2 \\
12 \\
4 \\
5 \\
4 \\
8 \\
8 \\
14 \\
4 \\
4 \\
5 \\
4 \\
3 \\
0\end{array}$ \\
\hline
\end{tabular}

Źródło: opracowanie własne na podstawie: Flash Eurobarometer 144 „Innobarometer”, Directorate General „Enterprise”, European Commission, luty 2004, tab. 1.3., s. 15.

agowania na potrzeby konsumentów jest bowiem umiejętność ich identyfikowania oraz zdolność zamiany pozyskanych informacji na wiedzę materializowaną w nowych produktach i procesach ich wytwarzania.

„Odpowiedź na potrzeby konsumentów”, traktowana jako czynnik motywujacy do działalności innowacyjnej, uzyskała wyraźną przewagę nad pozostałymi czynnikami, takimi jak:

- wzrastająca konkurencja cenowa (14\% odpowiedzi),

- potrzeba poprawy poziomu wydajności pracowników (13\% odp.),

- potrzeba poprawy poziomu wydajności maszyn i urządzeń (13\% odp.),

- wzrastająca konkurencja produktowa (11\% odp.),

- dostosowanie się do nowych regulacji lub zobowiązań prawnych (10\% odp.).

Poza odpowiedzią na potrzeby konsumentów, pozostałe czynniki mają zbliżone znaczenie dla badanych kierowników. Świadczy o tym zaledwie 4-proc. różnica w częstotliwości ich wskazywania.

Czynniki dostarczające najsilniejszych bodźców do wprowadzania innowacji można podzielić na:

- czynniki o charakterze endogenicznym (wewnętrznym):

$\checkmark$ potrzeba poprawy poziomu wydajności pracowników,

$\checkmark$ potrzeba poprawy poziomu wydajności maszyn i urządzeń;

- czynniki o charakterze egzogenicznym (zewnętrznym):

$\checkmark$ odpowiedź na potrzeby konsumentów,

$\checkmark$ wzrastająca konkurencja cenowa,

$\checkmark$ wzrastająca konkurencja produktowa, $\checkmark$ odpowiedź na nowe regulacje lub zobowiązania prawne.

W porównaniu z czynnikami endogenicznymi, czynniki egzogeniczne częściej odgrywały stymulacyjną funkcję do wprowadzania innowacji. Tak było w UE jako całości, a jak wyglądała struktura odpowiedzi w przekroju poszczególnych państw członkowskich? Niewątpliwie dostrzegalne jest duże zróżnicowanie oddziaływania poszczególnych czynników, zwłaszcza „odpowiedź na potrzeby konsumentów". Czynnik ten pobudzał do wprowadzania innowacji szczególnie kierowników w Niemczech (47\% odp.), Danii (46\% odp.) i Austrii (41\% odp.), w przeciwieństwie do kierowników we Włoszech (16\% odp.), Grecji (21\% odp.) i Belgii (22\% odp.). Powyżej przeciętnej dla UE czynnik ten wskazywano jeszcze w Wielkiej Brytanii (36\% odp.).

Należy podkreślić, że chęć zaspokojenia potrzeb konsumentów stanowiła najsilniejszy bodziec, najczęściej wymieniany przez kierowników we wszystkich państwach UE z wyjątkiem Włoch, gdzie funkcję tę spełniała potrzeba poprawy poziomu wydajności maszyn i urządzeń (33\% odp.).

W przypadku pozostałych czynników występujace rozbieżności ocen miały mniejszy zakres. Przykładowo dla $19 \%$ kierowników w Irlandii czynnik w postaci wzrastajacej konkurencji cenowej stanowił najsilniejszy bodziec do wprowadzania innowacji i tylko dla 9\% w Belgii i Hiszpanii. Dla 26\% kierowników Luksemburga takim czynnikiem była konieczność poprawy poziomu wydajności pracowników, ale w Austrii czynnik ten wskazało $5 \%$ odpowiadających. Dla $24 \%$ kierowników w Portugalii najsilniejszym stymulatorem innowacji była potrzeba poprawy poziomu wydajności maszyn i urządzeń, w przeciwieństwie do Danii 
i Niemiec, gdzie takich odpowiedzi było po 7\%. W Grecji $20 \%$ kierowników za najsilniejszy bodziec do wprowadzania innowacji uznało wzrastającą konkurencję produktową, przy 8-proc. wskazaniach w Austrii i Holandii. $\mathrm{Na}$ odpowiedź na nowe regulacje lub zobowiązania prawne, jako najważniejszy stymulator działalności innowacyjnej, najczęściej wskazywali kierownicy we Francji (19\% odp.), najrzadziej w Szwecji (3\% odp.).

Widoczne jest więc zróżnicowanie znaczenia poszczególnych czynników stanowiących bodźce do wdrażania innowacji w przekroju poszczególnych krajów. Czynniki endogeniczne względnie częściej wymieniano w Hiszpanii, Szwecji, Portugalii, Luksemburgu, Belgii, Grecji i Włoszech, w przeciwieństwie do Niemiec, Danii, Austrii, Wielkiej Brytanii, Finlandii i Francji, gdzie względną przewagę uzyskały czynniki egzogeniczne jako najważniejsze stymulatory wprowadzania innowacji.

Warto podkreślić, że w Finlandii i w Austrii aż 14\% i $12 \%$ kierowników nie było w stanie wskazać żadnego z wymienionych czynników jako bodźca do wdrażania innowacji.

\section{Struktura odpowiedzi według kategorii przedsiębiorstw}

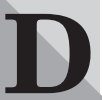

otychczasowe rozważania nad czynnikami dostarczającymi najsilniejszych bodźców do wprowadzania innowacji dotyczyły UE jako całości i poszczególnych państw członkowskich. Interesujący wydaje się rozkład odpowiedzi zależnie od kategorii przedsiębiorstw, dlatego też w tabeli 2 przedstawiono strukturę odpowiedzi z uwzględnieniem:

- przynależności sektorowej przedsiębiorstw,

- ich wielkości,

- okresu aktywności na rynku,

- udziału eksportu w obrotach ogółem.

Uwzględniajac pierwszy przekrój analizy: przynależność sektorową przedsiębiorstw - strukturę odpowiedzi, można stwierdzić, że dla wszystkich sektorów „odpowiedź na potrzeby konsumentów” stanowiła szczególnie ważny bodziec do wprowadzania innowacji, wyraźnie przewyższajacy pozostałe czynniki, $\mathrm{z}$ wyjątkiem sektora budowlanego, gdzie przewaga tego czynnika nad drugim w kolejności (wzrastającą konkurencją cenową) wynosiła tylko $2 \%$, a nad koniecznością poprawy poziomu wydajności pracowników $3 \%$.

Generalnie, częstotliwość wskazywania czynnika w postaci „odpowiedź na potrzeby konsumentów” była następująca:

- $42 \%$ kierowników w sektorze usług,

- $37 \%$ kierowników w sektorze handlu,

- $31 \%$ kierowników w sektorze przemysłowym,

- $22 \%$ kierowników w sektorze budowlanym.

W sektorach budowlanym oraz usług, częściej niż w pozostałych, wskazywano na czynniki endogeniczne jako na stymulatory wdrażania innowacji. Poza „odpowiedzią na potrzeby konsumentów” - najczęściej wskazywanym czynnikiem we wszystkich sektorach, w sektorze przemysłowym na drugim miejscu znalazł się czynnik w postaci „potrzeba poprawy poziomu wydajności maszyn i urządzeń (18\% odp.), w przeci-

Tab. 2. Czynniki dostarczajace najsilniejszych bodźców do wprowadzania innowacji w przedsiębiorstwie w ciągu ostatnich dwóch lat

\begin{tabular}{|c|c|c|c|c|c|c|c|}
\hline \multirow{3}{*}{ Wyszczególnienie } & \multicolumn{7}{|c|}{ Rodzaje czynników } \\
\hline & $\begin{array}{c}\text { Odpo- } \\
\text { wiedź na } \\
\text { potrzeby } \\
\text { konsu- } \\
\text { mentów }\end{array}$ & $\begin{array}{l}\text { Wzrasta- } \\
\text { jąca } \\
\text { konku- } \\
\text { rencja } \\
\text { cenowa }\end{array}$ & $\begin{array}{l}\text { Wzrasta- } \\
\text { jąca } \\
\text { konku- } \\
\text { rencja } \\
\text { produk- } \\
\text { towa }\end{array}$ & $\begin{array}{c}\text { Potrzeba } \\
\text { poprawy } \\
\text { poziomu } \\
\text { wydajno- } \\
\text { ści pra- } \\
\text { cowników }\end{array}$ & \begin{tabular}{|c|} 
Potrzeba \\
poprawy \\
poziomu \\
wydaj- \\
ności \\
maszyn \\
i urządzeń
\end{tabular} & \begin{tabular}{|c|} 
Dostoso- \\
wanie się \\
do nowych \\
regulacji \\
lub zobo- \\
wiązań \\
prawnych
\end{tabular} & $\begin{array}{c}\text { Brak } \\
\text { odpowie- } \\
\text { dzi }\end{array}$ \\
\hline & \multicolumn{7}{|c|}{ Procent odpowiedzi (przedsiębiorstw) } \\
\hline Unia Europejska (15 UE) & 35 & 14 & 11 & 13 & 13 & 10 & 4 \\
\hline $\begin{array}{l}\text { Sektory: } \\
\text { - przemysłowy } \\
\text { - budowlany } \\
\text { - handlu } \\
\text { - usług }\end{array}$ & $\begin{array}{l}31 \\
22 \\
37 \\
42\end{array}$ & $\begin{array}{r}16 \\
20 \\
17 \\
7\end{array}$ & $\begin{array}{r}16 \\
7 \\
11 \\
7\end{array}$ & $\begin{array}{r}8 \\
19 \\
11 \\
17\end{array}$ & $\begin{array}{l}18 \\
15 \\
10 \\
11\end{array}$ & $\begin{array}{r}7 \\
14 \\
10 \\
12\end{array}$ & $\begin{array}{l}4 \\
3 \\
5 \\
3\end{array}$ \\
\hline $\begin{array}{l}\text { Wielkość przedsiębiorstwa: } \\
\text { - } 20 \text { do } 49 \text { pracowników } \\
\text { - } 50 \text { do } 249 \text { pracowników } \\
\text { - } 250 \text { i więcej pracowników }\end{array}$ & $\begin{array}{l}36 \\
32 \\
44\end{array}$ & $\begin{array}{r}13 \\
16 \\
9\end{array}$ & $\begin{array}{l}10 \\
14 \\
15\end{array}$ & $\begin{array}{r}14 \\
12 \\
9\end{array}$ & $\begin{array}{r}14 \\
13 \\
7\end{array}$ & $\begin{array}{l}10 \\
10 \\
12\end{array}$ & $\begin{array}{l}4 \\
4 \\
3\end{array}$ \\
\hline $\begin{array}{l}\text { Okres aktywności na rynku: } \\
\text { - ponad } 30 \text { lat } \\
\text { - } 11 \text { do } 30 \text { lat } \\
\text { - } 0 \text { do } 10 \text { lat }\end{array}$ & $\begin{array}{l}32 \\
36 \\
41\end{array}$ & $\begin{array}{r}15 \\
14 \\
9\end{array}$ & $\begin{array}{l}11 \\
11 \\
10\end{array}$ & $\begin{array}{l}13 \\
12 \\
17\end{array}$ & $\begin{array}{l}14 \\
14 \\
11\end{array}$ & $\begin{array}{l}10 \\
10 \\
11\end{array}$ & $\begin{array}{l}5 \\
3 \\
2\end{array}$ \\
\hline $\begin{array}{l}\text { Udział eksportu: } \\
\text { - brak } \\
\text { - poniżej } 50 \% \\
\text { - } 50 \% \text { i więcej }\end{array}$ & $\begin{array}{l}36 \\
35 \\
35\end{array}$ & $\begin{array}{l}13 \\
14 \\
16\end{array}$ & $\begin{array}{r}8 \\
14 \\
14\end{array}$ & $\begin{array}{r}16 \\
9 \\
9\end{array}$ & $\begin{array}{l}12 \\
15 \\
14\end{array}$ & $\begin{array}{r}11 \\
9 \\
11\end{array}$ & $\begin{array}{l}4 \\
4 \\
2\end{array}$ \\
\hline
\end{tabular}

Źródło: opracowanie własne na podstawie: Flash Eurobarometer 144 „Innobarometer”, Directorate General „Enterprise”, European Commission, luty 2004, tab. 1.3., s. 15. 
wieństwie do dostosowania się do nowych regulacji lub zobowiązań prawnych (7\% odp.). W sektorze budowlanym drugim co do częstości wskazywania czynnikiem była wzrastająca konkurencja cenowa (20\% odp.). Natomiast wzrastająca konkurencja produktowa znalazła się na ostatnim miejscu (7\% odp.).

Również w sektorze usług wzrastającą konkurencję produktową oraz cenową, jako stymulatory innowacyjności, wskazywano najrzadziej (po $7 \%$ odp.). W sektorze tym na drugim miejscu znalazł się czynnik nazwany potrzeba poprawienia poziomu wydajności pracowników (17\% odp.). W sektorze handlu $17 \%$ kierowników uznało, że najbardziej motywowała ich do wdrażania innowacji wzrastająca konkurencja cenowa, w przeciwieństwie do potrzeby podwyższenia poziomu wydajności maszyn i urządzeń oraz dostosowania się do nowych regulacji lub prawnych zobowiązań, za którymi opowiedziało się po $10 \%$ respondentów.

Generalnie, wzrastającą konkurencję cenową najczęściej wskazywano w sektorze budowlanym (20\% odp.), najrzadziej w sektorze usług (7\% odp.). Wzrastająca konkurencję produktową najczęściej wymieniali kierownicy sektora przemysłowego (16\% odp.), najrzadziej sektorów budowlanego i usług (po 7\% odp.). Na potrzebę zwiększenia poziomu wydajności pracowników jako najsilniejszego bodźca do wprowadzania innowacji najczęściej wskazywali kierownicy w sektorze budowlanym (19\% odp.), najrzadziej w sektorze przemysłowym (8\% odp.). Zwiększenie wydajności maszyn i urządzeń to najsilniejszy bodziec dla $18 \%$ kierowników sektora przemysłowego i 10\% sektora handlu. Wreszcie dostosowanie się do nowych regulacji lub zobowiązań prawnych najczęściej wskazywali kierownicy sektora budowlanego (14\% odp.), najrzadziej sektora przemysłowego (7\% odp.).

Drugi przekrój analizy obejmuje: wielkość przedsiębiorstwa - strukturę odpowiedzi. Wszystkie przedsiębiorstwa, niezależnie od ich wielkości, najczęściej były stymulowane do wprowadzania innowacji chęcią zaspokojenia potrzeb konsumentów. Czynnik ten najczęściej wskazywali kierownicy przedsiębiorstw dużych (44\% odp.), następnie małych (36\% odp.) i najrzadziej średnich (32\% odp.). Przedsiębiorstwa duże, rzadziej niż pozostałe, wprowadzały innowacje pod wpływem czynników endogenicznych.

Wzrastająca konkurencja cenowa stanowiła najsilniejszy bodziec do wprowadzania innowacji najczęściej w przedsiębiorstwach średnich (16\% odp.), najrzadziej w firmach dużych (9\% odp.). Wzrastającą konkurencję produktową najczęściej wskazywali kierownicy przedsiębiorstw dużych (15\% odp.) w przeciwieństwie do $10 \%$ firm małych. Można to wytłumaczyć korzystnymi warunkami do rozwijania działalności innowacyjnej istniejącymi w dużych przedsiębiorstwach (własne zaplecze badawczo-rozwojowe, wykwalifikowana załoga, środki finansowe itp.). Konieczność podwyższenia poziomu wydajności pracowników stanowiła bodziec do wprowadzania innowacji w $14 \%$ firm małych i tylko 9\% firm dużych. Podobne proporcje dotyczyły kolejnego stymulatora, jakim jest potrzeba podwyższenia poziomu wydajności maszyn i urządzeń. Wskazało nań 14\% kierowników firm małych i $7 \%$ firm dużych. Dostosowanie się do nowych regulacji lub prawnych zobowiązań stanowiło najsilniejszy stymulator dla $12 \%$ przedsiębiorstw dużych i $10 \%$ firm małych.
Dominacja czynnika w postaci „odpowiedź na potrzeby konsumentów" występowała także w kolejnym przekroju analizy: okres funkcjonowania przedsiębiorstwa na rynku - struktura odpowiedzi. Pobudzał on do wprowadzania innowacji $41 \%$ kierowników firm młodych - funkcjonujących na rynku do 10 lat, 36\% kierowników firm średnich wiekowo (od 11 do 30 lat) i 32\% kierowników firm najstarszych - funkcjonujących na rynku ponad 30 lat. Można więc powiedzieć, że im starsza firma, tym chęć zaspokajania potrzeb konsumentów stawała się mniej odczuwalna jako bodziec do wprowadzania innowacji. W przedsiębiorstwach młodych drugim co do powszechności występowania czynnikiem była potrzeba poprawienia poziomu wydajności pracowników (17\% odp.), w przeciwieństwie do wzrastającej konkurencji cenowej, wskazanej przez 9\% kierowników.

Bardziej równomierny rozkład akcentów na poszczególne czynniki miał miejsce w pozostałych grupach przedsiębiorstw. W przedsiębiorstwach średnich wiekowo wzrastająca konkurencja cenowa i potrzeba zwiększenia wydajności maszyn i urządzeń stanowiły najsilniejszy bodziec do wprowadzania innowacji (po $14 \%$ odp.), częściej niż dostosowanie się do nowych regulacji lub zobowiązań prawnych (10\% odp.). Podobny układ priorytetów wystąpił w przedsiębiorstwach najstarszych, gdzie dla $15 \%$ kierowników wzrastajacca konkurencja cenowa najsilniej motywowała do działalności innowacyjnej.

Na zmianę poglądów kadry kierowniczej nie wpłynął zasadniczo udział eksportu w obrotach ogółem lub jego brak. Najczęściej wskazywanym czynnikiem motywujacym do wprowadzania innowacji były potrzeby konsumentów. Tak stwierdziło $36 \%$ kierowników przedsiębiorstw bez produkcji eksportowej i po $35 \%$ kierowników przedsiębiorstw z eksportem. Pozostałe czynniki wskazywano znacznie rzadziej. W przedsiębiorstwach bez produkcji eksportowej drugim co do powszechności występowania czynnikiem była potrzeba podwyższenia poziomu wydajności pracowników (16\% odp.). Na przeciwnym końcu skali znalazła się wzrastająca konkurencja produktowa (8\% odp.). Relacje te wskazuja, że kierownicy w mniejszym stopniu odczuwają konkurencję produktową jako presję na innowacje, jeżeli nie eksportują swoich wyrobów.

W przedsiębiorstwach eksportujących poniżej $50 \%$ produkcji na drugim miejscu pod względem częstotliwości występowania znalazł się endogeniczny czynnik w postaci konieczności podwyższenia poziomu wydajności maszyn i urządzeń (15\% odp.), w przeciwieństwie do potrzeby podwyższenia poziomu wydajności pracowników i dostosowania się do nowych regulacji lub zobowiązań prawnych (po 9\% odp.).

W przedsiębiorstwach, w których eksport stanowił $50 \%$ obrotów i więcej, na drugim miejscu znalazł się czynnik w postaci wzrastającej konkurencji cenowej (16\% odp.). Najmniej zwolenników zyskał endogeniczny czynnik, jakim jest konieczność zwiększenia poziomu wydajności pracowników (9\% odp.).

Generalnie, wzrastającą konkurencję cenową stanowiąca najsilniejszy bodziec do wprowadzania innowacji częściej wskazywali kierownicy przedsiębiorstw o największym eksporcie, w przeciwieństwie do tych bez produkcji eksportowej. Te ostatnie zaś częściej odczuwały potrzebę wprowadzania innowacji pod wpływem konieczności podwyższenia poziomu wy- 
dajności pracowników. Podwyższenie poziomu wydajności maszyn i urządzeń jako czynnik inspiracji innowacyjnej częściej odczuwano w firmach eksportujących, niż nie realizujących takiej produkcji. Również wzrastająca konkurencja cenowa częściej pobudzała do wdrażania innowacji kierowników firm eksportujaccych, niż bez produkcji eksportowej. Natomiast potrzeba dostosowania się do nowych regulacji lub prawnych zobowiązań stanowiła bodziec nieco częściej wskazywany przez kierowników firm bez produkcji eksportowej i eksportujących od 50\% swojej produkcji, w porównaniu z firmami, których eksport był mniejszy od $50 \%$.

\section{Zakończenie}

W odpowiedzi na pytanie postawione w tytule artykułu, na podstawie analizy poglądów kadry kierowniczej przedsiębiorstw funkcjonujących w dawnej UE, uzyskanych w wyniku badań empirycznych, można powiedzieć, że czynnikami dostarczającymi najsilniejszych bodźców do wprowadzania innowacji są: • czynniki egzogeniczne: $\vee$ odpowiedź na potrzeby konsumentów, $\nabla$ wzrastająca konkurencja cenowa, $\nabla$ wzrastająca konkurencja produktowa, $\checkmark$ dostosowanie się do nowych regulacji lub zobowiazań prawnych, - czynniki endogeniczne: $\nabla$ potrzeba podwyższenia poziomu wydajności pracowników, $\checkmark$ potrzeba podwyższenia poziomu wydajności maszyn i urządzeń.

Czynniki te inspirują do wdrażania innowacji zarówno technologicznych (produktowych i procesowych), jak i pozatechnologicznych (organizacyjnych, w metodach zarządzania, rynkowych).

Szczególnie ważnym bodźcem do wprowadzania innowacji we wszystkich obszarach funkcjonalnych przedsiębiorstwa wydaje się być „odpowiedź na potrzeby konsumentów" zarówno w UE jako całości, jak i w poszczególnych państwach członkowskich, zwłaszcza zaś w Niemczech, Danii i Austrii, w przeciwieństwie do Włoch, Grecji i Belgii.

Priorytet ten nie zmieniał się po uwzględnieniu kategorii przedsiębiorstw. Potrzeba zaspokojenia potrzeb konsumentów stała się najważniejszym motywem rozwijania działalności innowacyjnej i wdrażania jej produktów, w szczególności dla przedsiębiorstw: - należących do sektora usług, • dużych - zatrudniających 250 pracowników i więcej, • młodych - funkcjonujących na rynku od 0 do 10 lat, $\bullet$ nie realizujących produkcji eksportowej.

„Wzrastająca konkurencja cenowa” jako siła napędowa do wdrażania innowacji znalazła najliczniejsze poparcie kierowników w Irlandii, Danii, Finlandii, a także w przedsiębiorstwach: - sektora budowlanego, - średnich, zatrudniajacych od 50 do 249 pracowników, - najstarszych, funkcjonujących na rynku ponad 30 lat, eksportujących 50\% i więcej swojej produkcji.

Do wprowadzania innowacji, częściej niż gdzie indziej, motywowała kierowników „wzrastająca konkurencja produktowa”. Szczególnie dotyczyło to Grecji, Wielkiej Brytanii, Finlandii i Belgii oraz przedsiębiorstw: - należących do sektora przemysłowego, - dużych, zatrudniających 250 pracowników i więcej, - najstarszych i średnich wiekowo, eksportujących swoją produkcję.
Dostosowanie się do nowych regulacji lub zobowiązań prawnych stanowiło najsilniejszy bodziec do działalności innowacyjnej głównie we Francji, Austrii, Wielkiej Brytanii, Holandii i Belgii, a także w przedsiębiorstwach: - sektora budowlanego, - dużych, - młodych, • bez udziału produkcji eksportowej oraz eksportujaccych $50 \%$ i więcej swojej produkcji.

Potrzeba poprawy poziomu wydajności pracowników, jako czynnik endogeniczny, wydaje się pobudzać do wdrażania innowacji bardziej przedsiębiorstwa: - Luksemburga, Belgii i Grecji, - sektora budowlanego, $\bullet$ małe, $\bullet$ młode, $\bullet$ bez produkcji eksportowej.

Natomiast drugi czynnik endogeniczny w postaci „potrzeby poprawienia poziomu wydajności maszyn i urządzeń" stał się bodźcem do wprowadzania innowacji częściej w przedsiębiorstwach: • włoskich, portugalskich i hiszpańskich, • sektora przemysłowego, - małych, • najstarszych i średnich wiekowo, • eksportujacych poniżej 50\% swojej produkcji.

Generalnie, wśród krajów o zbliżonym do Polski poziomie rozwoju, a więc w Hiszpanii, Grecji i Portugalii, częstotliwość występowania czynników motywujących do wprowadzania innowacji była następująca: - odpowiedź na potrzeby konsumentów: w Hiszpanii $35 \%$ odpowiedzi, w Grecji $21 \%$ odpowiedzi, w Portugalii $29 \%$ odpowiedzi;

- zwiększajacca się konkurencja cenowa: w Hiszpanii $9 \%$ odpowiedzi, w Grecji 14\% odpowiedzi, w Portugalii $15 \%$ odpowiedzi;

- zwiększająca się konkurencja produktowa: w Hiszpanii $11 \%$ odpowiedzi, w Grecji $20 \%$ odpowiedzi, w Portugalii $10 \%$ odpowiedzi;

- dostosowanie się do nowych regulacji lub prawnych zobowiązań: w Hiszpanii 7\% odpowiedzi, w Grecji 10\% odpowiedzi, w Portugalii 6\% odpowiedzi;

- potrzeba poprawy poziomu wydajności pracowników: w Hiszpanii 14\% odpowiedzi, w Grecji 19\% odpowiedzi, w Portugalii 12\% odpowiedzi;

- potrzeba poprawy poziomu wydajności maszyn i urządzeń: w Hiszpanii 19\% odpowiedzi, w Grecji 14\% odpowiedzi, w Portugalii 24\% odpowiedzi.

dr inz. Jerzy Baruk

Uniwersytet Marii Curie-Skłodowskiej w Lublinie Instytut Zarządzania i Marketingu

\section{PRZYPISY}

1) Por. J. BARUK, Istota działalności innowacyjnej $i$ jej utrudnienia, [w:] Cztowiek i rynek, pod red. S. PARTYCKIEGO, Towarzystwo Naukowe KUL, Lublin 2004, t. 1, s. 231-237.

2) Por. Jak znajdować innowacje, „Zarządzanie na Świecie” 2004, nr 8, s. 16-17.

3) Por. Th. D. KUCZMARSKI, What is Innovation? And Why aren't Companies Doing More of It?, „Journal of Consumer Marketing" 2003, nr 6, s. 536.

4) Por. J. BARUK, Istota innowacji. Ewolucja systemów innowacyjnych, „Przegląd Organizacji” 2005, nr 1, s. 11-14 .

5) Por. Poszukiwanie innowacyjnych modeli biznesu, „Zarządzanie na Świecie" 2001, nr 10, s. 29-30.

6) Por. W. GRUDZEWSKI, I. HEJDUK, Projektowanie systemów zarzadzania, Difin, Warszawa 2001, s. 55.

7) Por. J. KARWOWSKI, Partnerstwo $w$ regionie - modny slogan czy determinanta rozwoju, [w:] Partnerstwo $w$ regionie, Uniwersytet Szczeciński, Szczecin 2004, s. 133.

8) J. BARUK, Charakterystyka dziatalności badawczo-rozwojowej, „Problemy Zarządzania” 2004, nr 1, s. 37.

9) Por. „Innobarometer”, European Commission, Directorate General Press and Communication, luty 2004.

10) Tamże, s. 3. 